\title{
Assessing the Impact of Non-Performing Loans on Economic Growth in Turkey
}

\author{
Dr. Aylin Erdoğdu \\ Istanbul Arel University, Turkey \\ aylinerdogdu@arel.edu.tr
}

\begin{abstract}
The purpose of this study is to determine the effects of non-performing loans (NPL) in the Turkish banking sector on the economic growth. An econometric model regarding the factors affecting the economic growth was created.

The present study has used the quarterly data between the years 1998Q1 and 2015Q3. Databases are provided by the Central Bank of the Republic of Turkey and Turkish Statistical Institute. Data analysis was performed with software package Eviews 8. The data analysis including the unit root test was conducted in the Augmented Dickey - Fuller (ADF) and Phillips - Perron (PP) methods and Granger causality test. In this study, unit root tests were carried out primarily in order to examine the stability of the series, and simple regression model was estimated as a result of the unit root tests. In the present study, the relationships were between variables in the determination of the model were estimated with ordinary least squares (OLS).

In accordance with the results of the empirical analyses in Turkey, there is a causality relationship between non-performing loans and domestic credit volume of the Turkish banking sector. Granger causality tests show that these relationships are bivious. Non-Performing Loans, gross domestic product (GDP) at constant prices, public sector expenditure at constant prices (PS) and private sector expenditure at constant prices (PSE), domestic credit volume (CV), total loan interest income (I) are the most significant sub-items of the economic growth. In another respect, it is expected to have the causality relationships between NLP, GDP, PE, PSE, CV and I which are the sub-items of the economic growth.
\end{abstract}

Keywords: Bank Loans, Economic Growth, Multivariate Regression Analysis, Non- Performing Loans.

\section{INTRODUCTION}

Banks collect funds from units with surplus funds and they are obliged to transfer these funds to the unit that needs funding. They carry out this task within the framework of activity, efficiency, and the opportunity cost principles. For these reasons, they are the most critical institutions of economy in terms of authority and responsibility (Erdoğdu 2015).

Non -performing loans can be defined as defaulted loans, from which banks are unable to profit. Loans usually fall due if no interest is paid in 90 days, but this may vary depending on countries and actors. Defaulted loans force banks to take certain measures in order to recover and securitize them in the best way. Loans become non-performing when they cannot be recovered within a certain stipulated time period that is governed by some respective laws so non-performing loan is defined from an institutional view point.

Growing non-performing loans negatively affect not only the banking sector, but also the national economy. If the least harmful effects of these problems cannot be overcome, they drag on new crises. Thus it causes a chaos 
in the country. Non-performing loans raise interest rates for bank loans that adversely affect the profitability of banks, and in this case leads to an increase in cost inflation.

Non-performing loans also adversely affect businesses. Types of loans used by businesses cause direct and indirect costs. Accrued expenses cause company bankruptcy, induces lost sales, rising credit costs and falling profitability.

To resolve these economic problems in the real sector is as important as keeping non-performing loans under control in banking sector. This paper seeks to determine which economic activity and variables affect non-performing loans in Turkey. The paper also includes a feedback response from non-performing loans to economic growth, using an econometric framework.

\section{LITERATURE REVIEW}

Jayaratne ve Strahan (1996) examined the panel data set issued by 50 USA States between 1972 and 1992. It was found that there is a relationship between increasing bank's loan quality with economic growth.

Demirgüç-Kunt ve Detragiache (1998) have examined pre- and post-crisis macro-economic variables in 36 countries. They found an increase in production over the banking crisis that caused a $4 \%$ decrease.

Keeton (1999) analyzed the increase in loan volume and the effects of debt repayment by using the vector auto regression model and the data between 1982 and 1996. In the study conducted in the United States, repayment of debts was defined as the failure to repay in the 90-day payment period. As a result, expansion of credit value has a strong correlation with declining assets.

Domaç and Peria (2000) explored the links between exchange rate regimes and financial stability and used logit analysis to calculate the probability of a banking crisis. They stated that a decrease in trade volume can negatively affect the borrowers' debt repayment and it would increase the probability of banking crisis.

In their study aiming to determine the factors affecting the non-performing loans in Spanish Banking Sector, Salas and Saurina (2002) concluded that real growth in GDP, bank size, market power and loan expansion affected non-performing loans.

Using panel data models in several sub-Saharan countries, Fofack (2005) revealed the existence of a relationship between the variables such as the economic growth, the real exchange rate increases, real interest rates, net interest earnings, and the debt that cannot be repaid in cash.

Podpiera and Weill (2008) examined the relationship between cost-effectiveness and NPL of the banking sector in the Czech Republic for the period of 1994-2005. They provided strong supporting evidence for mismanagement hypothesis and have claimed the need for the regulatory authorities in developing countries to focus on managerial performance in order to increase the stability of the financial system by reducing NPLs.

A. Çifter, Yilmazer, and E. Çifter (2009) conducted a study for June 2001-November 2007 period using the neural network method based on decomposition and stated that the industrial production has identified a delayed effect on the amount of NPL in the Turkish financial system.

Gilchrist and Zakrajsek (2011) have investigated the relationship between credit supply and bank lending conditions in the US economy in the data period of January 1952-April 2010 using VAR analysis data. The variables of the study are unemployment rate, industrial production index, inflation, bond premiums, consumer loans, business loans, a ten-year nominal treasury income, and nominal federal interest rate. Disruptions in the financial markets are measured by the increase in bond premium. It was found that the first reaction of banks to the financial problems in the financial markets is the rejection of loan applications and the reduction of credit 
amount in their balance sheets. Cyclical decline in business loans after a certain delay emerges as a key feature of the fluctuation.

In their study on the banks operating in the Central, Eastern and Southeast European countries, Jakubik and Reininger (2013) found that the leading economic variable that affects non-performing ratios of banks was economic growth and that there was a negative correlation between non-performing loan ratios and economic growth.

Mimir (2013) examined the 1987-2010 period for the US banking sector, bank loans, deposits, financial variables, such as the conjuncture of the net value of properties. One of the main findings obtained through the theoretical models is that financial shocks affect not only financial variables but also the macro variables.

Erdogdu (2015) carried out a survey to determine the relationship between the non-performing loans and bank's balance sheets effects and revealed that in most cases banking profitability advanced or emerged in parallel with public debt crisis. Banks have to continue their operations under the pressure of credit risk and the ratio of non-performing loans shows an increasing trend.

Studies on NPL in Turkey focus rather on macroeconomic activities. They handle the issue from the perspective of financial sophistication.

\section{METHODOLOGY AND FINDINGS}

The present study examined the correlation between the non-performing loans and macroeconomic variables between 1998Q1-2015Q3. The study examines whether there is a correlation between the growth in macroeconomic variables and change in non-performing loans ratio of Turkish Banking Sector. The selected variables for the start of the period to the first quarter of 1998 and current database have been updated to work with the last version of 2015Q3. Thus 1998-2015 period is selected. Time series databases are obtained from Turkey Statistical Institute (TSI), Turkey's Central Bank of the Republic of Turkey (CBRT) Electronic Data Delivery System and the Banks Association of Turkey (BAT).

In this study, E-Views 8 econometrics software package has been used to determine the time-series properties of the data related to the variables.

Liquidated receivables quarterly real growth rates (NPL) have been used as an indicator of non-performing loans while the expenditure method to the Gross Domestic Product the real growth rate (GDP) has been used as an indicator of macroeconomic variables. To refer to the total public sector expenditure real growth rate (at constant prices) (PE) has been used and (PSE) refers to total private sector spending real growth rate (at constant prices). The banking sector in domestic credit volume real growth rate has been indicated by (CV), and (I) has been used to refer to Deposits, Development and Investment Banks and Participation Banks' total loan interest income, accruals and rediscount.

Multiple regression model has been estimated by LSM (Least Squares Method)

\section{NPL: $\boldsymbol{\beta}_{0}+\boldsymbol{\beta}_{1} \mathrm{GDP}+\boldsymbol{\beta}_{2} \mathrm{PE}+\boldsymbol{\beta}_{3} \mathrm{PSE}+\boldsymbol{\beta}_{4} \mathrm{CV}+\boldsymbol{\beta}_{5} \mathrm{I}+\boldsymbol{\varepsilon}$}

$\varepsilon^{\prime}$ represents the error term of the model.

The model used in the present study is estimated by simple regression analysis.

Regression of a nonstationary time series on other nonstationary time series may produce a spurious regression. To avoid the spurious regression problem that may arise from the regression of a nonstationary time series on one or more nonstationary time series, we have to transform nonstationary time series to make them stationary. If we subject our time series data individually to unit root analysis and find that they are all I(1); i.e., they contain 
a unit root, there is a possibility of that our regression can still be meaningful (i.e., not spurious) provided that the variables are cointegrated. In order to find out whether they are cointegrated or not, we simply carry out our original regression and subject our error term to unit root analysis. If it is stationary; i.e., I(0), it means that our variables are cointegrated and have a long-term relationship between them. In short, provided that the residuals from our regression are I( 0$)$ or stationary, the conventional regression methodology is applicable to data involving nonstationary time series (Gujarati,2004).

Therefore, in order to apply ADF and PP unit root tests, all series are required to have stationary structure.

This study determined the stability of the extended series by using Augmented Dickey-Fuller (ADF TEST) unit root test and Phillips-Perron (PP) test.

The established standard procedure for cointegration analysis starts with the analysis of the unit root tests on the time series data. The Augmented Dickey-Fuller (ADF) and Phillips-Perron (PP) unit root tests are used to test for the presence of unit roots and establish the order of integration of the variables in the model.

ADF Test Model is mentioned below: (Fuller, 1976, p.308)

$\Delta y_{t}=\alpha+\beta t+\gamma y_{t-1}+\delta_{1} \Delta y_{t-1}+\cdots+\delta_{p-1} \Delta y_{t-p+1}+\varepsilon_{t}$,

PP Test Model is mentioned below: (Phillips ve Perron, 1988)

$\nabla=0$ (Means that; 1 . Differences)

$\nabla y_{t}=\nabla y_{t-1}+u_{t}$

Regression analysis is used when two or more variables are thought to be systematically connected by a linear relationship. In simple regression, we have only two - let us designate them $\mathrm{x}$ and $\mathrm{y}$ - and we suppose that they are related by an expression of the form.

Simple Linear Regression Model $\quad$.Multiple Linear Regression Model

$$
Y_{i}=\beta_{0}+\beta_{i} X_{i}+\varepsilon_{i} \quad Y=\beta_{0}+\beta_{1} X_{1}+\varepsilon
$$

We will leave aside for a moment the nature of the variable e and focus on the $\mathrm{x}-\mathrm{y}$ relationship, which is the equation of a straight line; b0 is the intercept (or constant) and b1 is the $\mathrm{x}$ coefficient, which represents the slope of the straight line the equation describes (Gujarati, 2004, p. 154).

Table 1. Unit Root Augmented -Dickey Fuller (ADF) Test Results

\begin{tabular}{|l|c|c|c|c|c|}
\hline Variables & $\begin{array}{c}\text { T Statistics } \\
\text { ADF }\end{array}$ & $\begin{array}{c}\text { T Statistics } \\
\mathbf{\% 1}\end{array}$ & $\begin{array}{c}\text { T Statistics } \\
\mathbf{\% 5}\end{array}$ & $\begin{array}{c}\text { T Statistics } \\
\mathbf{\% 1 0}\end{array}$ & Prob* $^{* 1}$ \\
\hline NPL & -4.141922 & -4.098741 & -3.477275 & -3.166190 & 0.0089 \\
\hline GDP & -3.900194 & -4.105534 & -3.480463 & -3.168039 & 0.0175 \\
\hline PE & -5.535893 & -4.110440 & -3.482763 & -3.169372 & 0.0001 \\
\hline PSE & -3.895250 & -4.105534 & -3.480463 & -3.168039 & 0.0177 \\
\hline CV & -4.442173 & -4.096614 & -3.476275 & -3.165610 & 0.0036 \\
\hline I & -9.243736 & -4.096614 & -3476275 & -3.165610 & 0.0000 \\
\hline
\end{tabular}

*MacKinnon (1996) one-sided p-values.

All series has taken first differences. 
American Research Journal of Business and Management (ARJBM)

Table 2: Unit Root Phillips Perron (PP)Test Results

\begin{tabular}{|l|c|c|c|c|c|}
\hline Variables & $\begin{array}{c}\text { Adj. T Sta- } \\
\text { tistics PP }\end{array}$ & $\begin{array}{c}\text { Adj. T Sta- } \\
\text { tistics \%1 }\end{array}$ & $\begin{array}{c}\text { Adj. T Statis- } \\
\text { tics \%5 }\end{array}$ & $\begin{array}{c}\text { Adj. T Statis- } \\
\text { tics \%10 }\end{array}$ & Prob* $^{*}$ \\
\hline NPL & -8.181842 & -4.096614 & -3.476275 & -3.165610 & 0.0000 \\
\hline GDP & -12.81108 & -4.096614 & -3.476275 & -3.165610 & 0.0001 \\
\hline PE & -30.30689 & -4.096614 & -3.476275 & -3.165610 & 0.0001 \\
\hline PSE & -8.127395 & -4.096614 & -3.476275 & -3.165610 & 0.0000 \\
\hline CV & -4.254857 & -4.096614 & -3.476275 & -3.165610 & 0.0064 \\
\hline I & -10.13043 & -4.096614 & -3.476275 & -3.165610 & 0.0000 \\
\hline
\end{tabular}

*MacKinnon (1996) one-sided p-values.

All series has taken first differences.

Table 3: Simple Linear Regression Model Results

\begin{tabular}{|l|l|l|l|l|}
\hline \multicolumn{1}{|c|}{ Dependent Variable: NPL } & & & & \\
\hline \multicolumn{1}{|c|}{ Method: Least Squares } & & & & \\
\hline Sample: 1998Q1 2015Q3 & & & & \\
\hline Included observations: 71 & & & & \\
\hline Variable & Coefficient & Std. Error & t-Statistic & Prob. \\
\hline GDP & 0.070202 & 0.036071 & 1.946223 & 0.0560 \\
\hline PE & -0.286389 & 0.282848 & -1.012520 & 0.3150 \\
\hline PSE & -0.819125 & 0.090878 & -9.013458 & 0.0000 \\
\hline CV & 0.013546 & 0.000739 & 18.32398 & 0.0000 \\
\hline I & 0.066438 & 0.015888 & 4.181698 & 0.0001 \\
\hline C & 2035076. & 413807.7 & 4.917925 & 0.0000 \\
\hline R-squared & 0.973210 & & & \\
\hline F-statistic & 472.2481 & Durbin-Watson stat & 0.890452 \\
\hline Prob(F-statistic) & 0.000000 & & & \\
\hline
\end{tabular}

Table 4: Engle Granger Causality Test Results

\begin{tabular}{|l|c|c|}
\hline \multicolumn{1}{|c|}{ Exogenous } & $\begin{array}{c}\text { Augmented Dickey Fuller Unit } \\
\text { Root Test Prob* }\end{array}$ & $\begin{array}{c}\text { Phillips Perron Unit Root Test } \\
\text { Prob* }\end{array}$ \\
\hline None & 0.0000 & 0.0000 \\
\hline Constant & 0.0006 & 0.0005 \\
\hline Constant Linear Trend & 0.0041 & 0.0035 \\
\hline
\end{tabular}

*MacKinnon (1996) one-sided p-values. 
American Research Journal of Business and Management (ARJBM)

Table 5: Autocorrelation Test Results

\begin{tabular}{|c|c|c|c|c|c|c|c|c|}
\hline \multicolumn{2}{|c|}{ Autocorrelation } & \multicolumn{3}{|c|}{ Partial Correlation } & $A C$ & PAC & Q-Stat & Prob \\
\hline 1 & $\square$ & 1 & $\sqsupset$ & 1 & 0.559 & 0.559 & 23.159 & 0.000 \\
\hline 1 & $\square$ & 1 & I & 2 & 0.316 & 0.005 & 30.658 & 0.000 \\
\hline 1 & $\boxminus$ & 1 & יו" & 3 & 0.266 & 0.127 & 36.049 & 0.000 \\
\hline 1 & $\square$ & 1 & $\boxminus$ & 4 & 0.388 & 0.281 & 47.712 & 0.000 \\
\hline 1 & ין & $\sqsubset$ & I & 5 & 0.186 & -0.243 & 50.436 & 0.000 \\
\hline 1 & י & 1 & b & 6 & 0.114 & 0.074 & 51.471 & 0.000 \\
\hline 1 & р & 1 & I & 7 & 0.093 & -0.010 & 52.177 & 0.000 \\
\hline 1 & $\boxminus$ & 1 & יاص & 8 & 0.245 & 0.174 & 57.124 & 0.000 \\
\hline 1 & 1 & $\sqsubset$ & I & 9 & 0.052 & -0.230 & 57.351 & 0.000 \\
\hline 1 & 1 & 1 & ص & 10 & 0.080 & 0.203 & 57.902 & 0.000 \\
\hline 1 & 1 & 1 & 1 & 11 & 0.074 & -0.068 & 58.372 & 0.000 \\
\hline 1 & $\boxminus$ & 1 & יا & 12 & 0.244 & 0.204 & 63.592 & 0.000 \\
\hline 1 & b & । & 1 & 13 & 0.080 & -0.175 & 64.157 & 0.000 \\
\hline 1 & 1 & 1 & 1 & 14 & 0.026 & 0.000 & 64.221 & 0.000 \\
\hline 1 & 1 & I & 1 & 15 & 0.018 & 0.029 & 64.250 & 0.000 \\
\hline 1 & ים & 1 & 1 & 16 & 0.148 & -0.008 & 66.312 & 0.000 \\
\hline
\end{tabular}

Table 6: Jarque Bera Test Of Normality Results

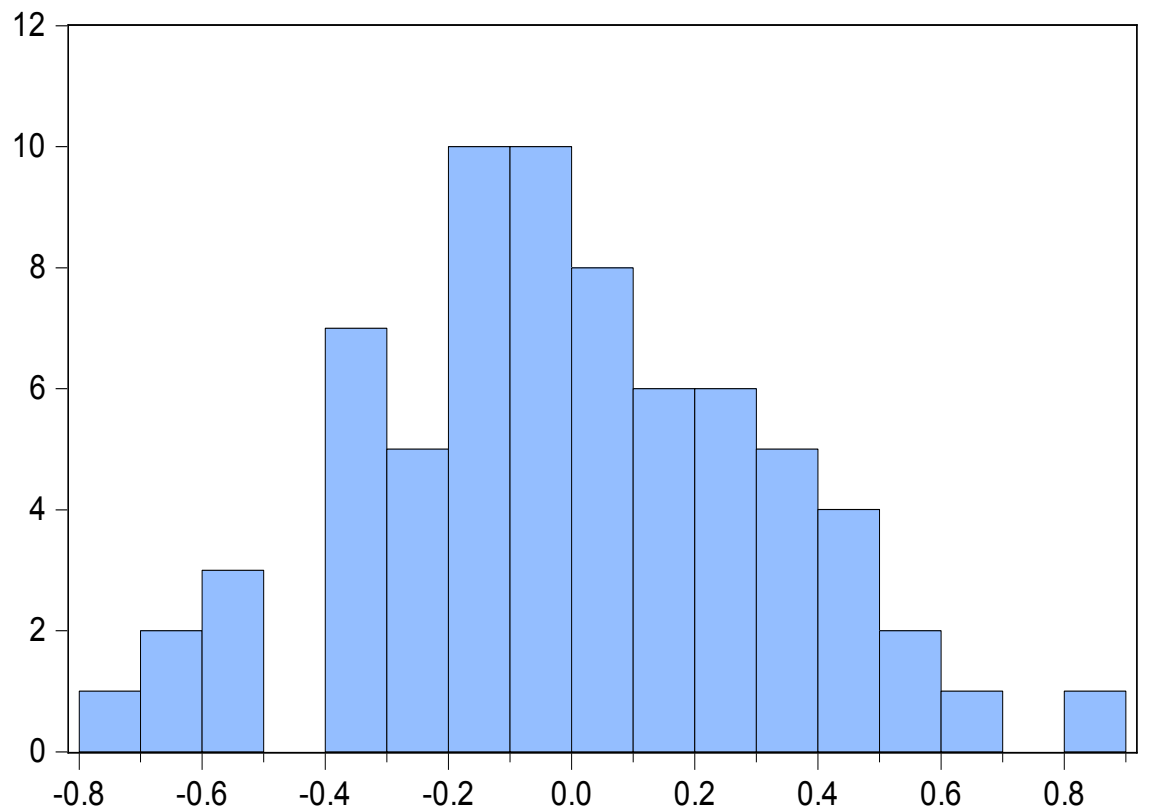

Series: Residuals

Sample 1998Q1 2015Q3

Observations 71

Mean

$1.60 \mathrm{e}-15$

Median $-0.025916$

Maximum

0.883714

Minimum

$-0.740750$

Std. Dev.

0.327674

Skewness $\quad 0.121794$

Kurtosis 2.857599

Jarque-Bera $\quad 0.235522$

Probability $\quad 0.888908$

Table 7: Contant Variation Test Results

\begin{tabular}{|l|l|l|l|}
\hline \multicolumn{3}{|l|}{ Heteroskedasticity Test: White } & \\
\hline F-statistic & 1.339430 & Prob. F(20,50) & 0.1994 \\
\hline Obs*R-squared & 24.76918 & Prob. Chi-Square(20) & 0.2104 \\
\hline Scaledexplained SS & 19.28163 & Prob. Chi-Square(20) & 0.5036 \\
\hline
\end{tabular}


American Research Journal of Business and Management (ARJBM)

Table 8: Multiple Linear Regression Model Results

\begin{tabular}{|l|l|l|l|}
\hline Dependent Variable: NPL & & & \\
\hline Method: Variance Inflation Factors & & & \\
\hline Sample: 1998Q1 2015Q3 & & & \\
\hline Included observations: 71 & & & \\
\hline & Coefficient & Uncentered & Centered \\
\hline Variable & Variance & VIF & VIF \\
\hline GDP & 0.001301 & 249.5083 & 12.42112 \\
\hline PE & 0.080003 & 25.26423 & 2.542351 \\
\hline PSE & 0.008259 & 59.54169 & 5.853109 \\
\hline CV & $5.46 \mathrm{E}-07$ & 11.37865 & 6.827936 \\
\hline I & 0.000252 & 29.00773 & 7.197199 \\
\hline C & $1.71 \mathrm{E}+11$ & 55.52178 & NA \\
\hline
\end{tabular}

\section{CONCLUSION}

Non-performing loans cause and result in harmful effects which are very much embedded in current economic structure.

Non-performing loans and banks will lead to costs for the banking sector. These costs are not only limited to the banks, they may apply to the general economy. For this purpose, the impact of non-performing loans on macro economic variables in Turkey's economy in the 1998Q1-2015Q3 period were examined.

Empirical determinants of NPL's presented in the present paper suggest that real GDP growth was the locomotive of non-performing loans. Therefore, reducing economic activity sustains the most important risk for bank asset quality.

According to the analysis of the results, the regression model confirms the analogous findings reported by other authors, growth in economic activity tends to lead to a decrease in non-performing loans; however, there is also a feedback effect from non-performing loans to real gross domestic product. The impact of the non-performing loans on banking sector statistically and significantly affects provided credit in a negative way.

Therefore, the increase in non-performing loans in Turkey will reduce growth, the banks' credit policy, management issues and the great significance of effective execution.

It can be concluded that the loans trading in banking sector, which is the major lending activity of the institution, is most exposed to credit risk. It is therefore expected that management will adopt very effective risk decreasing measures to improve the overall wealth status of the loan portfolio.

\section{REFERENCES}

Banking Regulations and Supervision Agency Web Page. www.bdkk.org.tr

Brooks, C., (2008), Introductory Econometrics for Finance, New York: Cambridge University Press.

Çifter, A., Yılmazer, S. \& Çifter E. (2009), Analysis of Sectoral Credit Default Cycle Dependency with WaveleNetworks: Evidence from Turkey, Economic Modelling 26, p. 1382-1388. 
Domaç, G. \& Peria S. M. (2000), Banking Crises and Exchange Rate Regimes: Is There a Link? World Bank.

Erdoğdu A, (2015), Non-performing Loans in Turkish Banking Sector and Balance Sheets Effects, JournalofModern Accounting and Auditing, Vol. 11, No. 12, 677-686.

Fuller, Wayne A.; (1976), Introduction to Statistical Time Series, John Wiley and Sons, ISBN0-471-28715-6,

New York.

Gilchrist, S., Zakrajsek, E. (2011), Bank Lending and Credit Supply Shocks, NBER Working Paper, No: 14863.

Gujarati, D.N.(2004) Basic Econometrics, Fourth edition, The McGraw-Hill, New York, p.154.

akubík Petr, Reininger Thomas,(2013,Q3) Determinants of Nonperforming Loans in Central, Eastern and Southeastern Europe, Focus On European Economic Integration.

Jayaratne, J and Strahan, P.E. (1996) The Finance -Growth Nexus: Evidence from Bank Branch Deregulation, The Quarterly Journal of Economics (1996) 111 (3): 639-670.

Mimir, Y. (2013), Financial Intermediaries, Credit Shocks and Business Cycles. TCMB Working Paper, No:13/13, 1-77.

Nkusu, M. (2011) ,Non-performing Loans and Macrofinancial Vulnerabilities in Advanced Economies Strategy, Policy and Review Department, IMF Working Paper, WP/11/161, Jully 2011.

Paul, K., R, Gurung, B., and Paul, A., K.,(Ed.) (2013), Recent Advances in Statistical Modelling Techniques, New Delhi, p. 281-288.

Phillips, C.B. Peter and Pierre Perron; (1988), Testing For A Unit Root in Time Series, Biometrika, 75(2), pp. 335-346.

Podpiera, J. \& Weill L., (2008), Bad Luck or Bad Management, Emerging Banking Market Experience, Journal of Financial Stability 4, p.135-148.

Salas, V. And Saurina, J., (2002), Credit Risk in Two Institutional Regimes "Spanish Commercial and Saving Banks" Journal of Financial Services Research, p.203-224.

Walsh, Carl E. ve James A. Wilcox (1995), How Is Bank Lending Related to Output ? , Federal Reserve Bank of Boston, Conference Series No:39, p.83-113.

Wojnilower, Albert. Not a Blown Fuse, Federal Reserve Bank of New York Quarterly Review, Spring 1993.

Citation: Dr. Aylin Erdoğdu, "Assessing the Impact of Non-Performing Loans on Economic Growth in Turkey”. ARJBM Volume 2016; pp:1-8

Copyright (c) 2016 Dr. Aylin Erdoğdu, This is an open access article distributed under the Creative Commons Attribution License, which permits unrestricted use, distribution, and reproduction in any medium, provided the original work is properly cited. 